\title{
Vibrio diazotrophicus sp. nov., a Marine Nitrogen-Fixing Bacterium
}

\author{
M. L. GUERINOT, ${ }^{\dagger} \dagger$ P. A. WEST, ${ }^{\prime}$ J. V. LEE, ${ }^{2}$ and R. R. COLWELL ${ }^{1}$ \\ Department of Microbiology, University of Maryland, College Park, Maryland 20742 ${ }^{1}$ and Public Health \\ Laboratory, Preston Hall Hospital, Maidstone ME20 7NH, United Kingdom ${ }^{2}$
}

\begin{abstract}
Facultatively anaerobic, nitrogen-fixing bacterial strains were isolated from sources as diverse as the gastrointestinal tracts of sea urchins collected in Nova Scotia, Canada, and the surfaces of reeds growing in a drainage ditch in Kent, England. These strains were placed in the genus Vibrio Pacini 1865 of the family Vibrionaceae on the basis of their morphological, physiological, and biochemical characteristics, as well as on the basis of the guanine-plus-cytosine contents of their deoxyribonucleic acids (45.9 to $47.2 \mathrm{~mol} \%)$. They were clearly distinguished from strains of the currently recognized species in the genus Vibrio by a combination of diverse traits, including the production of nitrogenase, the inability to hydrolyze casein, deoxyribonucleic acid, gelatin, and Tween 80 , the ability to ferment L-arabinose, cellobiose, salicin, and D-xylose, and the presence of an arginine dihydrolase system. Deoxyribonucleic acid homology studies supported recognition of these nitrogen-fixing strains as a new species, for which the name Vibrio diazotrophicus is proposed. Strain ATCC 33466 (= strain $1=$ NS1) is the type strain.
\end{abstract}

Species of Vibrio are ubiquitous in estuarine and oceanic environments and are commonly found in association with marine animals. Recently, Vibrio-like organisms capable of fixing $\mathrm{N}_{2}$ were isolated from the gastrointestinal tracts of temperate and tropical sea urchins $(6,7)$. These strains possessed certain characteristics that are unusual for vibrios, including the ability to ferment D-xylose and the inability to hydrolyze casein, deoxyribonucleic acid (DNA), gelatin, and Tween 80. These isolates were distinct from strains of any previously described Vibrio species and were classified as members of a marine Vibrio sp. pending the results of DNA homology studies.

Phenotypically similar organisms were identified during a numerical taxonomy study of group $\mathrm{F}$ vibrios (now designated Vibrio fluvialis) (11) and during a similar study of Vibrio species collected from natural waters in Kent, England (P. A. West, Ph.D. thesis, University of Kent at Canterbury, Kent, England, 1980). However, the ability of these strains to fix $\mathrm{N}_{2}$ was not determined.

The objectives of this study were to establish the nitrogen-fixing capability of the strains described by Lee et al. (11) and West (Ph.D.

\footnotetext{
† Present address: Michigan State University-Department of Energy Plant Research Laboratory, Michigan State University, East Lansing, MI 48824.
}

thesis) and to define the taxonomic status of the $\mathrm{N}_{2}$-fixing vibrios.

\section{MATERIALS AND METHODS}

Bacterial strains. The strains used in this study are listed in Table 1, together with their sources.

Characterization tests. The methods of Guerinot and Patriquin (6) were used to identify strains 1 through 3 , 14 , and 21 , and the methods of Lee et al. (11) were used to identify strains 4 through 13 and 15 through 20 , with the exceptions and additional tests noted below. Acid production from various substrates was determined for strains 4 through 13 and 15 through 20 in phenol red base broth (Difco Laboratories, Detroit, Mich.). Sulfatase and $o$-nitrophenyl- $\beta$-D-galactopyranoside tests were performed by the methods of Cowan (3) for strains 1 through 4. Tests for hydrolysis of albumin, elastin, lecithin, and chrondroitinase and tests for growth on ethanol, 1-propanol, melezitose, propionic acid, and $\mathrm{D}$-xylose were performed for strains 1 through 3 by using the methods of Lee et al. (11). The mode of flagellation of strains 5 through 13 was determined by electron microscopy, using the methods described of Lee et al. (11).

Nitrogenase activity. Nitrogenase activity was determined by the acetylene $\left(\mathrm{C}_{2} \mathrm{H}_{2}\right)$ reduction assay (8). Cultures were inoculated into malate glucose medium (6) and incubated at $25^{\circ} \mathrm{C}$. After $24 \mathrm{~h}$, tubes were closed with serum stoppers, and $0.2 \mathrm{ml}$ of $\mathrm{C}_{2} \mathrm{H}_{2}$ was injected into each tube. After incubation for 7 days, ethylene $\left(\mathrm{C}_{2} \mathrm{H}_{4}\right)$ production was analyzed by gas chromatography with a Shimadzu model GC-4BM gas chromatograph equipped with a flame ionization detector and operated at a column temperature of $50^{\circ} \mathrm{C}$; 
TABLE 1. Bacterial strains used in this study

\begin{tabular}{|c|c|c|c|}
\hline Strain no. or species & $\begin{array}{l}\text { Original strain } \\
\text { designation }\end{array}$ & Source & Site of isolation \\
\hline 1 & NS1 & M. L. Guerinot ${ }^{a}$ & $\begin{array}{l}\text { Sea urchin gastrointestinal tract, } \\
\text { Nova Scotia, Canada }\end{array}$ \\
\hline 2 & NS2 & M. L. Guerinot ${ }^{a}$ & $\begin{array}{l}\text { Sea urchin gastrointestinal tract, } \\
\text { Nova Scotia, Canada }\end{array}$ \\
\hline 3 & $\mathrm{CB} 42$ & M. L. Guerinot ${ }^{\prime \prime}$ & Water, Chesapeake Bay, Maryland \\
\hline 4 & VL 6110 & J. V. Lee ${ }^{b}$ & Water. Humber River, England \\
\hline 5 & P103 & P. A. West & $\begin{array}{l}\text { Ditch water. Chetney Marsh, } \\
\text { England }\end{array}$ \\
\hline 6 & P104 & P. A. West & $\begin{array}{l}\text { Ditch water, Chetney Marsh, } \\
\text { England }\end{array}$ \\
\hline 7 & P105 & P. A. West & $\begin{array}{l}\text { Ditch water, Chetney Marsh, } \\
\text { England }\end{array}$ \\
\hline 8 & P106 & P. A. West & $\begin{array}{l}\text { Ditch water, Chetney Marsh, } \\
\text { England }\end{array}$ \\
\hline 9 & P107 & P. A. West & $\begin{array}{l}\text { Ditch sediment, Chetney Marsh, } \\
\text { England }\end{array}$ \\
\hline 10 & $\mathrm{P} 108$ & P. A. West & $\begin{array}{l}\text { Ditch sediment, Chetney Marsh, } \\
\text { England }\end{array}$ \\
\hline 11 & P109 & P. A. West & $\begin{array}{l}\text { Reed surface, Chetney Marsh, } \\
\text { England }\end{array}$ \\
\hline 12 & P110 & P. A. West & $\begin{array}{l}\text { Ditch water, Chetney Marsh, } \\
\text { England }\end{array}$ \\
\hline 13 & P111 & P. A. West & $\begin{array}{l}\text { Ditch water. Chetney Marsh, } \\
\text { England }\end{array}$ \\
\hline 14 & Bar & M. L. Guerinot" & $\begin{array}{l}\text { Sea urchin gastrointestinal tract, } \\
\text { Barbados }\end{array}$ \\
\hline 15 & VL 1491 & J. V. Lee ${ }^{h}$ & Oysters \\
\hline 16 & VL 2610 & J. V. Lee ${ }^{h}$ & Cockles \\
\hline 17 & VL 4780 & J. V. Lee ${ }^{h}$ & Oysters \\
\hline 18 & VL 5802 & J. V. Lee ${ }^{h}$ & Cockles \\
\hline 19 & VL 5815 & J. V. Lee ${ }^{b}$ & Cockles \\
\hline 20 & VL 5970 & J. V. Lee ${ }^{b}$ & Whelks \\
\hline 21 & 31 & C. R. McClung & $\begin{array}{l}\text { Roots of Spartina alterniflora, } \\
\text { Chesapeake Bay salt marsh, } \\
\text { Maryland }\end{array}$ \\
\hline \multicolumn{4}{|l|}{ Culture collection strains } \\
\hline Vibrio alginolyticus & ATCC 17749 & $\mathrm{ATCC}^{d}$ & \\
\hline Vibrio anguillarum & ATCC 14181 & ATCC & \\
\hline Vibrio cholerae & ATCC 14035 & $\mathrm{ATCC}$ & \\
\hline Vibrio metschnikovii & NCTC 11170 & NCTC & \\
\hline Vibrio parahaemolyticus & ATCC 17802 & ATCC & \\
\hline Oceanospirillum beijerenckii & ATCC 12754 & ATCC & \\
\hline Oceanospirillum linum & ATCC 11336 & ATCC & \\
\hline Oceanospirillum maris subsp. maris & ATCC 27509 & ATCC & \\
\hline Vibrio nereis & ATCC 25917 & $\mathrm{ATCC}$ & \\
\hline Vibrio fluvialis & NCTC 11327 & NCTC & \\
\hline
\end{tabular}

"See reference 6 .

${ }^{b}$ See reference 11 .

c C. R. McClung, Plant Virology Laboratory, Agricultural Research Service, U.S. Department of Agriculture, Beltsville Agricultural Research Center-West, Beltsville, Md.

"ATCC, American Type Culture Collection, Rockville, Md.

"NCTC, National Collection of Type Cultures. Central Public Health Laboratory, London, England.

the carrier gas flow rate was $25 \mathrm{ml} / \mathrm{min}$ in a column $(0.32$ by $50 \mathrm{~cm}$ ) packed with 80 - to 100 -mesh Porapak $T$. The retention times for $\mathrm{C}_{2} \mathrm{H}_{4}$ and $\mathrm{C}_{2} \mathrm{H}_{2}$ were 15 and $30 \mathrm{~s}$, respectively.

DNA extraction. Cells were grown overnight in 1 liter of $1 \%$ tryptone- $3 \% \mathrm{NaCl}$ broth at $30^{\circ} \mathrm{C}$ with agitation. The cells were harvested by centrifugation, washed twice with TS buffer $[0.05 \mathrm{M}$ tris(hydroxy- methyl)aminomethane (Tris), $0.1 \mathrm{M} \mathrm{NaCl}, \mathrm{pH}$ 8.1], and the DNA was extracted by a modification of the method of Marmur (12). Cells suspended in $50 \mathrm{ml}$ of TES buffer $(0.05 \mathrm{M}$ tris, $0.05 \mathrm{M}$ ethylenedinitrilotetraacetic acid [disodium salt], $0.1 \mathrm{M} \mathrm{NaCl}, \mathrm{pH} 8.1$ ) were lysed by adding $5 \mathrm{ml}$ of $20 \%$ sodium dodecyl sulfate, after which the suspension was incubated with $50 \mu \mathrm{g}$ of pronase $(75,000 \mathrm{U} / \mathrm{g}$; Calbiochem, La Jolla, Calif.) 
per $\mathrm{ml}$ for $2 \mathrm{~h}$ at $37^{\circ} \mathrm{C}$. The suspension was then extracted three times with TES buffer-saturated phenol and then three times with chloroform-isoamyl alcohol (24:1). The DNA was precipitated with ethanol, spooled, and dissolved in $0.1 \times \mathrm{SSC}(1 \times \mathrm{SSC}$ is $0.15 \mathrm{M} \mathrm{NaCl}$ plus $0.015 \mathrm{M}$ sodium citrate, $\mathrm{pH} 7.0$ ). The DNA solution was adjusted to $1 \times \mathrm{SSC}$ and then incubated with $50 \mu \mathrm{g}$ of ribonuclease per $\mathrm{ml}$ for $2 \mathrm{~h}$ at $37^{\circ} \mathrm{C}$. The DNA was deproteinized by two extractions with TES buffer-saturated phenol and chloroformisoamyl alcohol, precipitated with ethanol, and dissolved in $0.1 \times \mathrm{SSC}$.

$\mathbf{G}+\mathbf{C}$ content of the DNA. The guanine-plus-cytosine $(\mathrm{G}+\mathrm{C})$ content of the DNA was determined by the buoyant density method (16) or was calculated from the thermal denaturation temperature (13), as determined with a Gilford model 2400 spectrophotometer. DNA having a buoyant density $1.731 \mathrm{~g} / \mathrm{ml}$ prepared from Micrococcus lysodeikticus (Sigma Chemical Co., London, England) and DNA from Escherichia coli strain WP2, which contained $51.0 \mathrm{~mol} \% \mathrm{G}+\mathrm{C}(15)$, were used as the reference DNAs in the buoyant density and thermal denaturation procedures, respectively.

Preparation of radioactively labeled DNA. DNA was labeled in vitro with $\left[\alpha-{ }^{32}\right.$ P]deoxycytosine triphosphate (specific activity, $>400 \mathrm{Ci} / \mathrm{mmol}$ ) by the nicktranslation method according to the instructions of the manufacturer (Amersham Corp., Arlington Heights, Ill.), with the following modification. The nick-translation reaction was stopped by loading the reaction mixture directly onto a $8-\mathrm{cm}$ column of Bio-Gel P60 suspended in buffer containing $0.05 \mathrm{M}$ Tris base, 0.05 $\mathrm{M}$ ethylenedinitrilotetraacetic acid (disodium salt), and $0.1 \mathrm{M} \mathrm{NaCl}, \mathrm{pH}$ 8.1. Fractions $(200 \mu \mathrm{l})$ were collected and monitored for radioactivity. The specific activities of the labeled DNA preparations were approximately $2 \times 10^{7} \mathrm{cpm} / \mu \mathrm{g}$ of DNA.

DNA-DNA hybridization. Type strains of both Vibrio and Oceanospirillum species were used in the DNADNA hybridization studies. The genetic relatedness of strains was determined by DNA-DNA hybridization on membrane filters. Native DNA $(10 \mu \mathrm{g} / \mathrm{ml}$ in $0.1 \times$ SSC) was denatured by adding 0.1 volume of $1 \mathrm{~N}$ $\mathrm{NaOH}$. After incubation for $10 \mathrm{~min}$ at room temperature, the DNA solution was neutralized by adding 0.1 volume $1.8 \mathrm{M}$ Tris-hydrochloride-0.2 $\mathrm{M}$ Tris base. The concentration of DNA was adjusted to $5 \mu \mathrm{g} / \mathrm{ml}$ in $6 \times$ SSC. Samples $(10 \mathrm{ml})$ of these DNA solutions were passed by gravity filtration through nitrocellulose filters (type BA85; diameter, $25 \mathrm{~mm}$; pore size, $0.45 \mu \mathrm{m}$; Schleicher \& Schuell Co., Keene, N.H.) that had previously been soaked in $6 \times \mathrm{SSC}$ and washed with 20 $\mathrm{ml}$ of the same solution. Retention of DNA was estimated by monitoring the optical density of the filtrates at $260 \mathrm{~nm}$. The filters were washed with $20 \mathrm{ml}$ of $6 \times \mathrm{SSC}$, air dried at room temperature, and subsequently placed in a vacuum oven at $80^{\circ} \mathrm{C}$ for $2 \mathrm{~h}$. Loaded filters were preincubated in Denhardt solution (4) to which $0.01 \%$ sodium dodecyl sulfate had been added. The filters were then transferred to vials containing $10^{4}$ to $10^{5} \mathrm{cpm}$ of denatured labeled DNA in 2 $\mathrm{ml}$ of Denhardt solution supplemented with $0.01 \%$ sodium dodecyl sulfate. The vials were incubated at $65^{\circ} \mathrm{C}$ for $24 \mathrm{~h}$. After incubation, each filter was washed three times with $20 \mathrm{ml}$ of $3 \times \mathrm{SSC}$, air dried, and counted in $10 \mathrm{ml}$ of scintillation fluid with a Beckman model LS-3155T or LS-7500 liquid scintillation counter.

\section{RESULTS AND DISCUSSION}

All of the strains in phenon 4 of West (strains 5 through 13) (West, Ph.D. thesis) and two of the strains in phenon 5 of Lee et al. (11) (strains 4 and 15) demonstrated nitrogenase activity. Of the two strains in phenon 5 which fixed $\mathrm{N}_{2}$, only strain 4 was positive for arginine dihydrolase and phenotypically indistinguishable from strains 1 and 2 . Indeed, strain 4 showed $95 \%$ homology to strain 1 when these strains were examined by DNA-DNA hybridization (Table 2). The other nitrogenase-positive strain in phenon 5 was more similar to strain 14 ; it was not able to decarboxylate the amino acids arginine, lysine, and ornithine and had the ability to hydrolyze gelatin. Strains 14 and 15 showed only 4 and $13 \%$ homology, respectively, to strain 1 (Table 2).

The strains in phenon 5 of Lee et al. (11) which did not fix $\mathrm{N}_{2}$ differed in a number of traits from strains 1 and 2. These nitrogenasenegative strains were also indole and methyl red

TABLE 2. DNA-DNA hybridization relationships of $V$. diazotrophicus strain 1 to other strains of $V$. diazotrophicus and to strains of Vibrio and Oceanospirillum

\begin{tabular}{|c|c|c|}
\hline Strain or species & $\begin{array}{c}\text { Relate } \\
\text { to } \\
\text { diazotro } \\
\text { strain }\end{array}$ & $\begin{array}{l}\text { dness } \\
V . \\
\text { phicus } \\
(\%)^{\prime \prime}\end{array}$ \\
\hline 3 & 100 & $(1)^{b}$ \\
\hline 4 & 94.7 & (2) \\
\hline 5 & 87.7 & (2) \\
\hline 8 & 100 & (3) \\
\hline 9 & 62 & (3) \\
\hline 13 & 100 & (3) \\
\hline 14 & 12.7 & (3) \\
\hline 15 & 4 & (1) \\
\hline 16 & 4.8 & (3) \\
\hline 17 & 11.0 & (3) \\
\hline 18 & 10.3 & (3) \\
\hline 19 & 4.6 & (3) \\
\hline 20 & 5.7 & (3) \\
\hline 21 & 33.3 & (3) \\
\hline Vibrio alginolyticus & 5 & (1) \\
\hline Vibrio anguillarum & 0.7 & (1) \\
\hline Vibrio cholerae & 8.8 & (1) \\
\hline Vibrio fluvialis & 4 & (3) \\
\hline Vibrio metschnikovii & 4 & (1) \\
\hline Vibrio nereis & 6.0 & (3) \\
\hline Vibrio parahaemolyticus & 12.7 & (3) \\
\hline Oceanospirillum beijerinckii & 2.0 & (3) \\
\hline Oceanospirillum linum & 1.3 & (1) \\
\hline Oceanospirillum maris subsp. maris & 1.5 & (3) \\
\hline
\end{tabular}

${ }^{a}$ Arithmetic means of percentages of relatedness, as determined by DNA-DNA hybridization.

${ }^{b}$ The numbers in parentheses are numbers of determinations. 
negative and possessed the ability to hydrolyze Tween 80 . In addition, two of the strains produced gas from glucose. The nitrogenase-negative strains examined in this study demonstrated only 5 to $11 \%$ homology to strain 1 (Table 2 ). Therefore, these strains were not considered to be taxonomically related to strain 1 .

We also concluded that strain 21 was not related to strain 1; strain 21 showed only $33.3 \%$ homology to strain 1 . Strain 21 was included in the study because it was isolated from an estuarine environment, demonstrated an ability to fix $\mathrm{N}_{2}$, and had a $\mathrm{G}+\mathrm{C}$ content of $46 \mathrm{~mol} \%$. This strain is phenotypically similar to other strains included in this study (C. R. McClung, personal communication).

Of the four strains in phenon 4 included in the hybridization study, three showed 88 to $100 \%$ homology to strain 1 (Table 2). However, strain 9 was only $62 \%$ homologous to strain 1 (Table 2) and differed in a number of traits from strains 1 and 2 ; e.g., it showed no growth at $42^{\circ} \mathrm{C}$, produced acid from mannose, hydrolyzed urea, and grew on L-serine. Although $62 \%$ homology can be considered a low homology value for strains included within a single species, for the present we conclude that strain 9 belongs to the same species as strain 1 .

Strain 1 showed very little homology to representatives of other species of Vibrio or to selected Oceanospirillum spp. (Table 2). Oceanospirillum strains were included in the DNA-DNA hybridization studies even though the metabolism of these strains is strictly respiratory because their DNAs have approximately the same $\mathrm{G}+\mathrm{C}$ contents as the DNAs of the $\mathrm{N}_{2}$-fixing vibrios. Like the $\mathrm{N}_{2}$-fixing vibrios, they are oxidase-positive and require salt for growth. In addition, members of the Spirillaceae have been shown to fix $\mathrm{N}_{2}(14,20,21)$, whereas before the work of Guerinot and Patriquin $(6,7)$ the ability to fix $\mathrm{N}_{2}$ had not been reported for any member of the Vibrionaceae.

Strain 1 was selected as the type strain of a new species, for which the name Vibrio diazotrophicus is proposed. Strains 1 through 13 are considered to belong to $V$. diazotrophicus. The phenotypic traits of $V$. diazotrophicus are listed in Tables 3 through 5. The DNA base compositions of selected strains of $V$. diazotrophicus and of other strains used in this study are given in Table 6. Traits which distinguish $V$. diazotrophicus from other arginine dihydrolase-positive Vibrio species are given in Table 7.

Phenotypically, $V$. diazotrophicus comprises a very well-defined cluster of strains. Like many other species of Vibrio, if this species is grown in liquid media, the cells have a single, long-wavelength flagellum which is sometimes sheathed (Fig. 1). On solid media, the cells may also
TABLE 3. Biochemical characteristics of $V$. diazotrophicus for which all strains are positive

Fermentative in oxidation/fermentation medium Motility

Catalase production

Oxidase production

Indole production

Methyl red reaction

Growth in $3 \% \mathrm{NaCl}$

Growth at:

$20^{\circ} \mathrm{C}$

$37^{\circ} \mathrm{C}$

Arginine dihydrolase

Nitrate reduction

$o$-Nitrophenyl- $\beta$-D-galactopyranoside reaction

Susceptibility to $0 / 129(150 \mu \mathrm{g} / \mathrm{ml})$

Amylase

Nitrogenase

Phosphatase

Acid production from:

L-Arabinose

Arbutin

Cellobiose

Glucose

Mannitol

Salicin

Sucrose

Trehalose

D-Xylose

Growth on:

Acetate

D-Alanine

L-Alanine

L-Arginine

Cellobiose

Citrate

Glutamate

L-Proline

Pyruvate

Salicin

Succinate

D-Xylose

possess lateral, unsheathed flagella having a shorter wavelength (Fig. 2). Characteristically, strains of $V$. diazotrophicus produce only a limited range of extracellular enzymes and are not able to hydrolyze casein, chitin, DNA, gelatin, lecithin, and Tween 80 . Lack of extracellular enzymes apparently is very unusual in the genus Vibrio (1), as is the ability to ferment or grow on D-xylose as the sole source of carbon (11). However, until more species of Vibrio have been described, such a generalization may be premature. Strains of $V$. diazotrophicus yield reactions similar to those of Vibrio anguillarum in the tests routinely used for identification of members of the Vibrionaceae. Nevertheless, $V$. diazotrophicus strains can be distinguished easily by a few tests (Table 7).

In a study of Beneckea Reichelt et al. (18) reported that two closely related strains (strains 
TABLE 4. Biochemical characteristics of $V$. diazotrophicus for which all strains are negative

Gram reaction

Gas from glucose

Growth in:

$0 \% \mathrm{NaCl}$

$8 \% \mathrm{NaCl}$

Lysine decarboxylase

Ornithine decarboxylase

Voges-Proskauer reaction

$\mathrm{H}_{2} \mathrm{~S}$ production

Swarming on solid media

Hemolysis

Luminescence

Acid production from:

Inositol

Sorbitol

Albumin hydrolysis

Casein hydrolysis

Chitinase

Chondroitinase

Deoxyribonuclease

Elastin hydrolysis

Gelatin hydrolysis

Lecithinase

Tween 80 hydrolysis

Growth on:

Formate

Glycine

Melizitose

Proprionate

Sorbitol

Ethanol

1-Propanol

84 and 85 ) had little relationship to other strains of Beneckea; these strains are now regarded as members of Vibrio (1) and are similar to $V$. diazotrophicus in that they are arginine dihydrolase positive, lack the extracellular enzymes gelatinase and lipase, and have similar $\mathrm{G}+\mathrm{C}$ contents. However, in a numerical taxonomy study in which 148 characteristics were used (West, Ph.D. thesis), these strains did not cluster with strains of phenon 4. Therefore, it is unlikely that they are related to $V$. diazotrophicus.
TABLE 6. DNA base compositions of selected strains of $V$. diazotrophicus and other strains used in this study

\begin{tabular}{cc}
\hline \multicolumn{1}{c}{ Strain } & $\begin{array}{c}\mathrm{G}+\mathrm{C} \text { content of DNA } \\
(\mathrm{mol} \%)\end{array}$ \\
\hline $\begin{array}{l}\text { V. diazotrophicus } \text { strains } \\
1\end{array}$ & 45.9 \\
2 & 46.6 \\
4 & 46.1 \\
5 & 46.1 \\
7 & 46.1 \\
8 & 47.2 \\
9 & 46.8 \\
11 & 46.5 \\
Other strains & \\
14 & 48.4 \\
15 & 47.9 \\
16 & 46.3 \\
20 & 47.0 \\
21 & 46.0 \\
\hline
\end{tabular}

West (Ph.D. thesis) tentatively suggested the name "Vibrio fossarum" (fossarum, meaning of ditches, referring to the original site of isolation) for strains 5 through 13 and stated that additional data, including DNA-DNA hybridization data and $G+C$ values, would be required to confirm the taxonomic status of these strains. As this name has not been validly published, the name $V$. diazotrophicus is here proposed for this organism.

Because the $\mathrm{N}_{2}$-fixing isolates are facultatively anaerobic, oxidase-positive, rigid, gram-negative, motile rods having a single polar flagellum, we concluded that they belong to the family Vibrionaceae. They are placed in the genus Vibrio on the basis of their susceptibility to the vibriostatic agent $0 / 129(150 \mu \mathrm{g} / \mathrm{ml})$, their DNA base composition ( 45 to $47 \mathrm{~mol} \% \mathrm{G}+\mathrm{C}$ ), their anaerogenic fermentation of glucose, their production of a sheathed polar flagellum, and their requirement for $\mathrm{NaCl}$. Inclusion of $\mathrm{N}_{2}$-fixing strains in the genus Vibrio requires a redefinition of the genus since the current definition of

TABLE 5. Biochemical characteristics of $V$. diazotrophicus for which strain differences were observed

\begin{tabular}{lccc}
\hline \multicolumn{1}{c}{ Characteristic } & $\begin{array}{c}\text { No. of strains } \\
\text { positive }\end{array}$ & $\begin{array}{c}\text { Reaction of } \\
\text { type strain" }\end{array}$ & $\begin{array}{c}\text { Strain giving less } \\
\text { frequent result }\end{array}$ \\
\hline Growth at $4^{\circ} \mathrm{C}$ & 12 & + & 13 \\
Growth at $42^{\circ} \mathrm{C}$ & 9 & + & $3,9,10,11$ \\
Acid from mannose & 2 & - & 9,10 \\
Acid from rhamnose & 6 & - & $1,2,4,5,6,7$ \\
Sulfatase & 3 & - & $5,7,11$ \\
Urease & 1 & - & 9 \\
Growth on L-serine & 3 & & $9,10,11$ \\
Growth on threonine & 6 & $4,5,6,8,11,12$ \\
\hline
\end{tabular}

"In each case 13 strains were tested.

${ }^{b}$ Strain 1 (= ATCC 33466) 
TABLE 7. Characteristics useful in distinguishing strains of $V$. diazotrophicus from phenotypically similar bacteria $^{a}$

\begin{tabular}{|c|c|c|c|c|c|c|c|}
\hline \multirow[b]{2}{*}{ Character } & \multicolumn{7}{|c|}{ Reaction of: } \\
\hline & $\begin{array}{c}V . \\
\text { diazotrophicus }\end{array}$ & $\begin{array}{c}V . \\
\text { anguillarum }\end{array}$ & $\begin{array}{c}V . \\
\text { nereis }\end{array}$ & $\begin{array}{c}V . \\
\text { metschnikovii }\end{array}$ & $\begin{array}{c}\text { V. } \\
\text { fluvialis }\end{array}$ & $\begin{array}{c}\text { Vibrio } \\
\text { proteolyticus }\end{array}$ & $\begin{array}{c}\text { Vibrio } \\
\text { splendidus I }\end{array}$ \\
\hline Luminescence & - & - & - & - & - & - & + \\
\hline Gas from glucose & - & - & - & - & $\mathrm{v}$ & - & - \\
\hline Oxidase & + & + & + & - & + & + & + \\
\hline Nitrate reduction & + & + & + & - & + & + & + \\
\hline Indole & + & $\mathrm{v}$ & + & $\mathrm{v}$ & - & + & $++^{\circ}$ \\
\hline Methyl red & + & - & + & + & + & + & $-c^{\prime}$ \\
\hline Nitrogenase & + & - & - & - & - & - & - \\
\hline Voges-Proskauer & - & + & - & + & - & + & - \\
\hline \multicolumn{8}{|l|}{ Acid from: } \\
\hline L-Arabinose & + & $\mathrm{v}$ & - & - & + & - & - \\
\hline Cellobiose & + & + & - & - & $\mathrm{v}$ & + & + \\
\hline Salicin & + & - & - & - & v & - & $-r$ \\
\hline D-Xylose & + & - & - & - & - & - & - \\
\hline Casein hydrolysis & - & + & - & + & + & + & $\mathrm{v}^{\prime}$ \\
\hline Chitinase & - & + & + & + & + & + & + \\
\hline Deoxyribonuclease & - & + & + & + & + & + & + \\
\hline Gelatinase & - & + & - & + & + & + & + \\
\hline Lecithinase & - & v & - & + & + & + & $+c$ \\
\hline Tween 80 hydrolysis & - & + & - & + & + & + & + \\
\hline
\end{tabular}

${ }^{a}$ Data from this study and references $5,10,11,18$ and 19, except as noted below.

${ }^{b}-$, Negative; + , positive; $v$, variable between strains.

'Data from West (Ph.D. thesis).

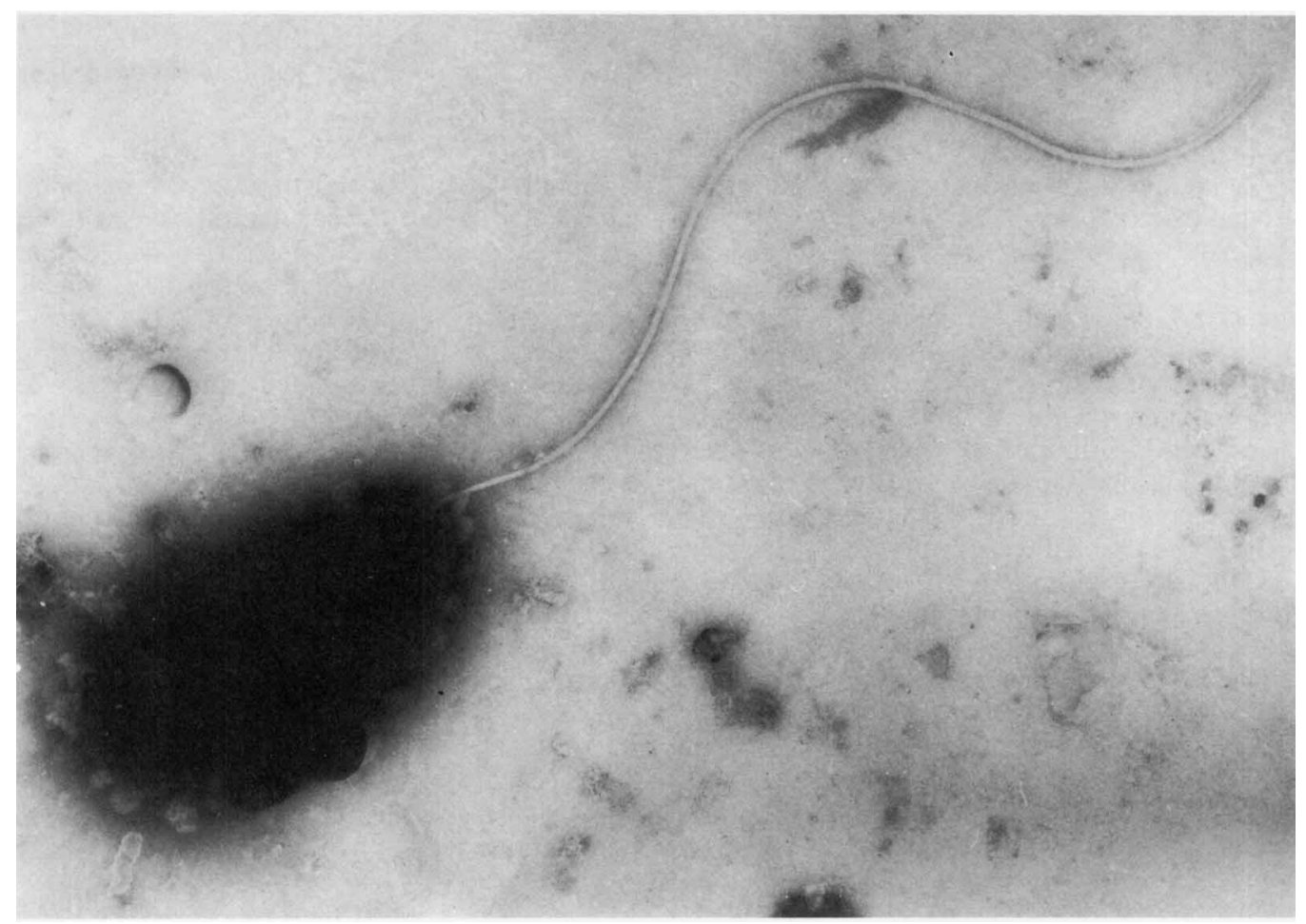

FIG. 1. V. diazotrophicus strain 8 grown for $4 \mathrm{~h}$ in a broth culture, showing a sheathed, long-wavelength polar flagellum. $\times 21,000$. 


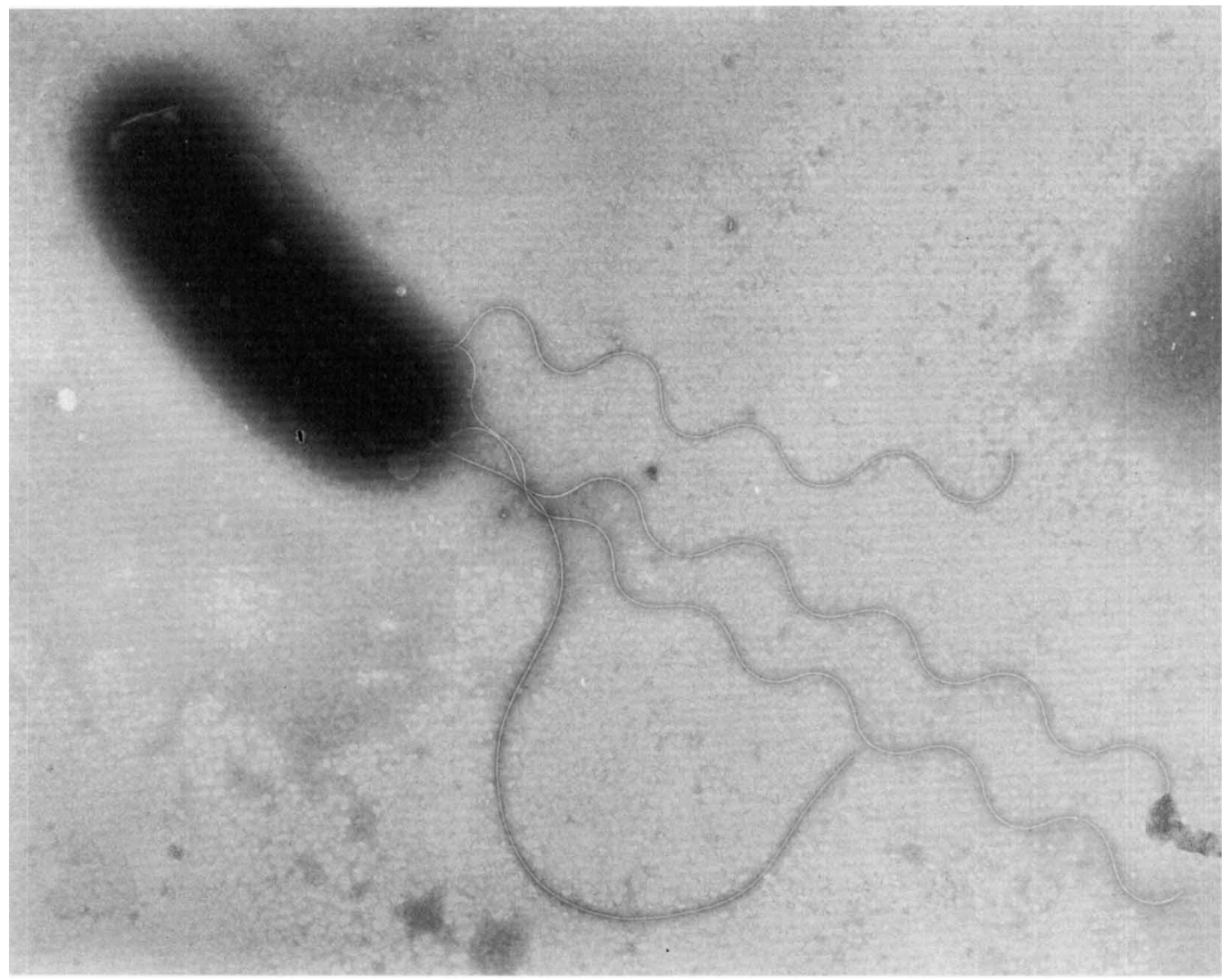

FIG. 2. $V$. diazotrophicus strain 5 grown for $8 \mathrm{~h}$ on marine agar, showing a polar flagellum and three shortwavelength lateral flagella. $\times 14,000$.

Vibrio states that no species fixes molecular nitrogen (1).

It is not surprising that vibrios that are capable of fixing $\mathrm{N}_{2}$ exist. Indeed, the ability to fix $\mathrm{N}_{2}$ is widespread among bacterial genera, but it is often found in only one or two species or strains within a genus $(2,17)$. The ability of vibrios to fix $\mathrm{N}_{2}$ may prove to be important in certain marine habitats limited by available nitrogen since organisms capable of nitrogen fixation have the potential for significantly affecting the nitrogen budget of their surroundings. The role of the $\mathrm{N}_{2}$-fixing vibrios in the nitrogen cycle of estuarine and marine environments remains to be elucidated (9).

Vibrio diazotrophicus sp. nov. (di.a.zo.tro'.phi. cus. Gr. prefix di two, double; NL.n. azotum nitrogen; Gr. n. trophos one that feeds; L. suffix icus relating to; ML. adj. diazotrophicus one that feeds on dinitrogen). Gram-negative, short rods. 0.5 by 1.5 to $2.0 \mu \mathrm{m}$; axis straight or curved. Cells occur singly or are sometimes united into S-shapes or spirals. No resting stages have been observed. Cells are motile by means of a single polar flagellum, which may be sheathed when the cells are grown in liquid media. On solid media, lateral, unsheathed, short-wavelength flagella may be produced. Colonies on marine agar (Difco) are flat, circular, and off-white. Strains fail to grow in the absence of sodium chloride. Facultatively anaerobic. Acid, but not gas, produced from glucose. Reduces nitrates to nitrites. Oxidase, catalase, and nitrogenase are produced. Gelatinase, deoxyribonuclease, and chitinase are not produced. Voges-Proskauer negative. The $\mathrm{G}+\mathrm{C}$ content of the DNA ranges from 45.9 to $47.2 \mathrm{~mol} \%$.

Habitat: distributed throughout marine and estuarine environments, occurring in seawater, sediments, and the gastrointestinal tracts of marine animals.

Type strain: ATCC 33466. The description of the type strain is the same as that given above for the species. The base composition of its DNA is $45.9 \mathrm{~mol} \% \mathrm{G}+\mathrm{C}$, as determined by the buoyant density method.

\section{ACKNOWLEDGMENTS}

We thank L. A. McNicol for invaluable assistance and advice with the DNA procedures and C. R. McClung for 
encouragement during the study and for a critical reading of the manuscript. We are also grateful to A. A. Porter for assistance with the electron microscopy, to L. R. Hill for allowing us to use the facilities of the National Collection of Type Cultures to determine the DNA base compositions, and to R. J. Owen for advice and assistance in these determinations.

Support was provided by grant DEB-77-14646 from the National Science Foundation.

\section{REPRINT REQUESTS}

Address reprint requests to: Dr. R. R. Colwell, Department of Microbiology, University of Maryland, College Park, MD 20742 .

\section{LITERATURE CITED}

1. Baumann, P., L. Baumann, S. S. Bang, and M. J. Woolkalis. 1980. Reevaluation of the taxonomy of Vibrio, Beneckea and Photobacterium: abolition of the genus Beneckea. Curr. Microbiol. 4:127-132.

2. Burns, R. C., and R. W. F. Hardy. 1975. Nitrogen fixation in bacteria and higher plants. Springer-Verlag, New York.

3. Cowan, S. T. 1974. Cowan and Steel's manual for the identification of medical bacteria, 2nd ed. Cambridge University Press, New York.

4. Denhardt, D. T. 1966. A membrane-filter technique for the detection of complementary DNA. Biochem. Biophys. Res. Commun. 23:641-646.

5. Furniss, A. L., J. V. Lee, and T. J. Donovan. 1978. The vibrios. Public Health Laboratory Service Monograph Series, no. 11. Her Majesty's Stationery Office, London.

6. Guerinot, M. L., and D. G. Patriquin. 1981. $\mathrm{N}_{2}$-fixing vibrios isolated from the gastrointestinal tract of sea urchins. Can. J. Microbiol. 27:311-317.

7. Guerinot, M. L., and D. G. Patriquin. 1981. The association of $\mathrm{N}_{2}$-fixing bacteria with sea urchins. Mar. Biol. 62:197-207.

8. Hardy, R. W. F., R. D. Holsten, E. K. Jackson, and R. C. Burns. 1968. The acetylene-ethylene assay for $\mathrm{N}_{2}$ fixation: laboratory and field evaluation. Plant Physiol. 43:11851207.

9. Knowles, R. 1977. The significance of asymbiotic dinitrogen fixation by bacteria, p. 34-83. In R. W. F. Hardy and A. H. Gibson (ed.), A treatise on dinitrogen fixation, sect. 4. Agronomy and ecology. John Wiley \& Sons, Inc., New York.

10. Lee, J. V., T. J. Donovan, and A. L. Furniss. 1978. Char- acterization, taxonomy, and emended description of Vibrio metschnikovii. Int. J. Syst. Bacteriol. 28:99-111.

11. Lee, J. V., P. Shread, A. L. Furniss, and T. N. Bryant. 1981. Taxonomy and description of Vibrio fuvialis $\mathrm{sp}$. nov. (synonym group $F$ vibrios, group EF6). J. Appl. Bacteriol. 50:73-94.

12. Marmur, J. 1961. A procedure for the isolation of deoxyribonucleic acid from microorganisms. J. Mol. Biol. 3:208-218.

13. Marmur, J., and P. Doty. 1962. Determination of the base composition of deoxyribonucleic acid from its thermal denaturation temperature. J. Mol. Biol. 5:109-118.

14. McClung, C. R., and D. G. Patriquin. 1980. Isolation of a nitrogen-fixing Campylobacter species from the roots of Spartina alterniflora Loisel. Can. J. Microbiol. 26:881886.

15. Nishibuchi, M., K. Muroga, R. J. Seidler, and J. L. Fryer. 1979. Pathogenic Vibrio isolated from cultured eels. IV. Deoxyribonucleic acid studies. Bull. Jpn. Soc. Sci. Fish. 45:1469-1473.

16. Owen, R. J., and L. R. Hill. 1979. Estimation of base composition, base pairing and genome sizes of bacterial deoxyribonucleic acids, p. 277-296. In F. A. Skinner and D. W. Lovelock (ed.), Identification methods for microbiologists, 2nd ed. Academic Press, Inc., London.

17. Postgate, J, R. 1974. Evolution within nitrogen-fixing systems, p. 263-293. In M. J. Carlile and J. J. Shehel (ed.), Evolution in the microbes. Cambridge University Press, New York.

18. Reichelt, J. L., P. Baumann, and L. Baumann. 1976. Study of genetic relationships among marine species of the genera Beneckea and Photobacterium by means of in vitro DNA/DNA hybridization. Arch. Microbiol. 110:101-210.

19. Schubert, R. H. W. 1969. Aeromonas hydrophila subsp. proteolytica comb. nov. Zentralbl. Bakteriol. Parasitenkd. Infektionskr. Hyg. Abt. 1 Orig. 211:409-412.

20. Strength, W. J., B. Isani, D. M. Linn, F. D. Williams, G. E. Vandermolen, B. E. Laughon, and N. R. Kreig. 1976. Isolation and characterization of Aquaspirillum fasciculus sp. nov., a rod-shaped nitrogen-fixing bacterium having unusual flagella. Int. J. Syst. Bacteriol. 26:253268.

21. Tarrand, J. J., N. R. Krieg, and J. Dobereiner. 1978. A taxonomic study of the Spirillum lipoferum group, with descriptions of a new genus, Azospirillum gen. nov., and two species, Azospirillum lipoferum (Beijerinck) comb. nov. and Azospirillum brasiliense sp. nov. Can. J. Microbiol. 24:967-980. 